\title{
THE EFFECT OF WORK ENGAGEMENT AND RELIGIOSITY ON BURNOUT AMONG DENTISTS AT PRIMARY CARE CLINICS
}

\author{
Mira Zoraya, Heru Kurnianto Tjahjono, Arlina Dewi
}

Masters Program of Hospital Management, Universitas Muhammadiyah Yogyakarta

\begin{abstract}
Background: Burnout is caused by work-related stressors and often occurs among dentists. Work stress, long working hours, low work engagement may have a negative effect on the psychological well-being and family life of the dentist. It can affect the quality of care and workforce retention. Previous studies showed that religiosity is a protective factor in coping stress. This study aimed to determine the effect of work engagement and religiosity on burnout among dentists at primary care clinics.

Subjects and Method: This was a cross sectional study conducted at Yogyakarta in Juli 2019. A sample of 75 dentists was selected for this study. The dependent variable was burnout. The Independent variables were work engagement and religiousity. The work engagment was measuraed by UWES (Utretch Work Engagement Scale). The burnout was measured by MBI (Maslach Burnout Inventory). Other data was collected by questionnaire. The data were analyzed by a multiple logistic regression.

Results: Work engagement was asssociated with burnout among dentist.

Conclusion: Work engagement is asssociated with burnout among dentist.
\end{abstract}

Keywords: work engagement, religiosity, burnout, dentist.

Correspondence:

Mira Zoraya. Masters Program of Hospital Management, Universitas Muhammadiyah Yogyakarta, Bantul. Email: mirazoraya@gmail.com. Mobile: 081802703800.

The $6^{\text {th }}$ International Conference on Public Health Best Western Premier Hotel, Solo, Indonesia, October 23-24, 2019 | 141 https://doi.org/10.26911/the6thicph.02.48 